\title{
Sedimentary records of 2010 and 2011 Warta River seasonal floods in the region of Poznań, Poland
}

\author{
Katarzyna SKOLASIŃSKA ${ }^{1, *}$, Witold SZCZUCIŃSKI ${ }^{1}$, Marta MITRĘGA ${ }^{1}$, \\ Robert JAGODZIŃSKI ${ }^{1}$ and Stanisław LORENC ${ }^{1}$
}

1 Adam Mickiewicz University in Poznań, Institute of Geology, Maków Polnych 16, 61-606 Poznań, Poland

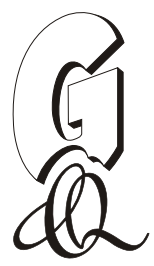

Skolasińska, K., Szczuciński, W., Mitręga, M., Jagodziński, R., Lorenc, S., 2015. Sedimentary records of 2010 and 2011 Warta River seasonal floods in the region of Poznań, Poland. Geological Quarterly, 59 (1): 47-60, doi: 10.7306/gq.1179

The Warta River near Poznań (West Poland) represents a meandering lowland river modified by hydro-engineering projects. Recently, two large floods occurred during the summer of 2010 and the winter of 2011. Rapid response surveys were conducted to document erosion and sedimentary records of the floods (spatial extent, grain size, composition, grain microtextures). Follow-up studies, which were conducted during the two years after the floods, assessed postdepositional changes in the flood deposits. A thick sand layer formed that ranged from an average of 10-15 cm (summer) to $30-35 \mathrm{~cm}$ (winter), building natural levees, side bars and crevasse splays. The sand layers consisted of fine- and medium-grained sands that were well-sorted, fine skewed and sourced from the river channel. The longer but smaller winter flood produced thicker and coarser deposits at different sites compared with the summer flood. An organic-rich mud layer and algal mats, which were short-existing, were also detected on the floodplain. The study proved that the flood record on engineered rivers may be only in the sand bodies near the river channel and their preservation is mainly controlled by their thickness. A single site may not record all floods, as particular events tend to leave deposits in various places.

Key words: lowland river, flood deposits, overbank sedimentation, postdepositional changes, Warta River, Central Europe.

\section{INTRODUCTION}

River floods comprise an important natural hazard. The assessment of their risk requires knowledge of the extent and frequency of previous events. This information is necessary for planning flood protection structures, which are usually constructed with the consideration of the largest flood during the last hundred or thousand years. As recorded human history is usually too short to cover these time periods, sedimentary archives must be searched to determine the frequency, duration and extent of previous floods for the assessment of flood hazards (e.g., Falkowski, 1975; Gonera, 1986; Kalicki, 1996, 2000; Gębica and Sokołowski, 2001; Szmańda et al., 2004; Kaczmarczyk et al., 2008). These geological records are critical to the discussion of increase in extreme rainfall related to the climate change, that generates larger and more frequent floods (e.g., Milly et al., 2002; Kundzewicz et al., 2010).

The majority of data on modern flood deposits is derived from post-flood surveys; for instance, surveys in the Sudety mountains in Poland (Teisseyre, 1985, 1988; Zieliński, 2001, 2003), the Parsęta River valley in Poland (Zwoliński, 1985,

\footnotetext{
* Corresponding author; e-mail: katskol@amu.edu.pl
}

Received: May 9, 2014; accepted: July 16, 2014; first published online: July 17, 2014
1992), the river valleys in Japan (Iseya, 1989), the Rhine and Meuse River valleys in the Netherlands (Asselman and Middelkoop, 1995), the Tuross River in Australia (Ferguson and Brierley, 1999), the Danube River valley in Slovakia (Lehotský et al., 2010), the South Saskatchewan River valley in Canada (Smith and Pérez-Arlucea, 2008; Smith et al., 2010) and the Mississippi River valley (e.g., Farrell, 1987; Gomez et al., 1997; Khan et al., 2013). These field investigations of floodplain sedimentation are accompanied by numerous laboratory experiments (e.g., Bathurst et al., 2002; Fraselle et al., 2010) and numerical modelling (e.g., Marriott, 1992). These studies show that river flood sedimentation is significantly conditioned by local factors and remains poorly understood. The studies of modern flood deposits also revealed that these deposits differed from older flood records preserved in sedimentary rock (Brierley et al., 1997; Hudson, 2005). These differences may be related to the effects of postdepositional processes, which have not been substantially investigated (Teisseyre, 1988; Zwoliński, 1992; Benito et al., 2003; Skolasińska and Rotnicka, 2011).

Prolonged and torrential rains in May 2010 resulted in a major flood that affected the majority of the countries in central Europe (Bissolli et al., 2011). In Poland, this flood appeared to be the largest flood during the last 130 years in the Wisła River basin (e.g., Zajacczkowski et al., 2010; Wierzbicki et al., 2013) and one of the largest floods in recent history of the Warta River (Fig. 1 and Table 1). Several months after this event, the Warta River valley was flooded again in the winter of 2010/2011 (Skolasińska and Rotnicka, 2011). These two floods provided the opportunity to examine the sedimentological effects of ma- 

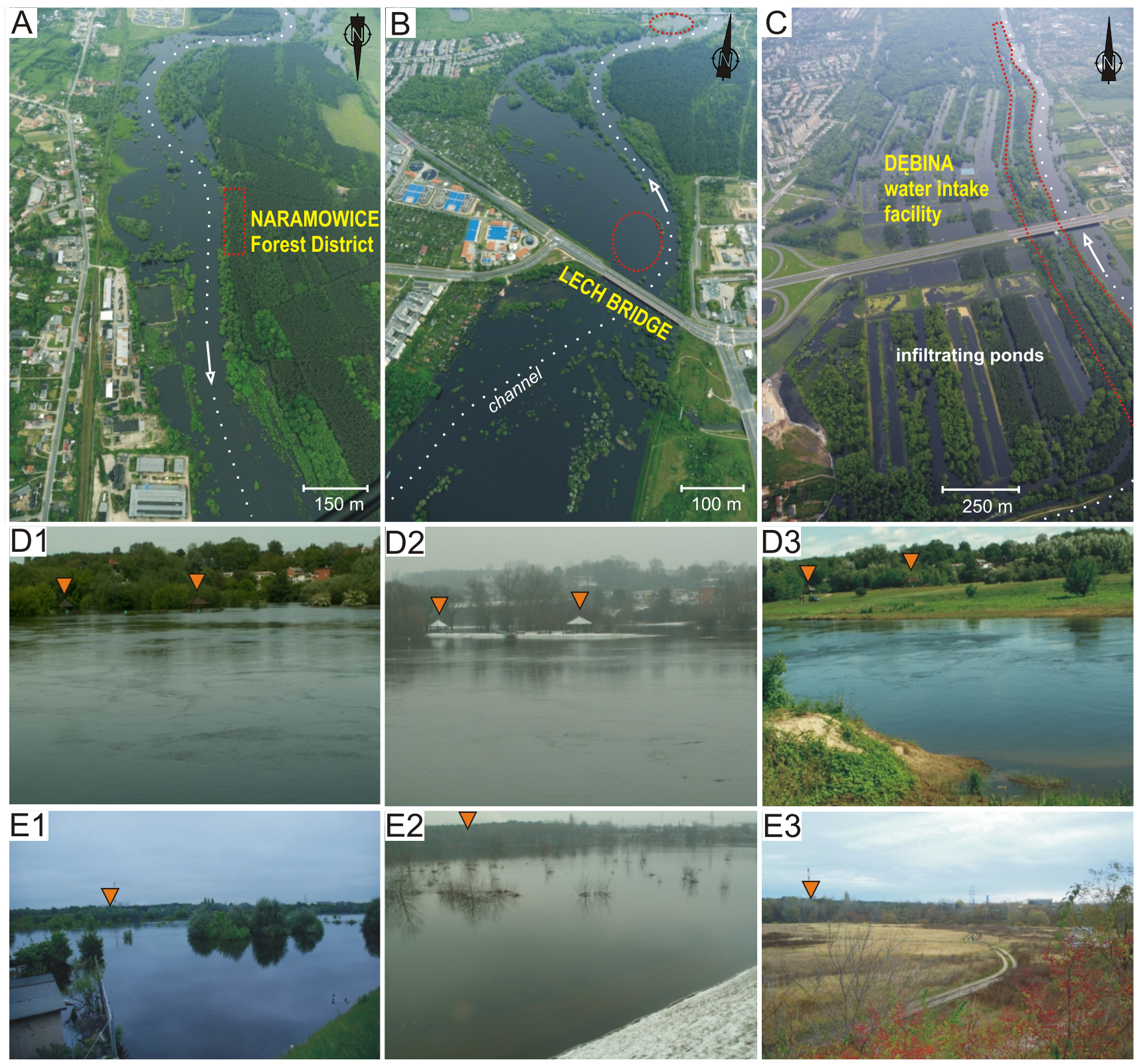

Fig. 1. Photographs of the study area during the floods $A$ to $C$; aerial pictures presenting the maximum summer flood in 2010 (after Kaczmarczyk, 2010); note the various orientations; fields encircled with dots denote approximate locations of the sampling sites, which are represented on Figure 2B, C

A - flooded river terraces near Naramowice Forest District; B - flooded area near Lech Bridge; C - inundated water intake area at Debina river channel is on the right; D1-D3 - the present Warta River valley near the Naramowice Forest District; the pictures were taken during D1summer flood 2010, D2 - winter flood 2011, and D3 - average flow conditions; the red triangles denote the same orientation points; E1-E3 present the Warta River valley near the Lech Bridge; the pictures were taken during E1 - summer flood 2010, E2 - winter flood 2011, and E3 - average flow conditions; red triangles denote the same orientation points

jor seasonal floods and the preservation potential of flood deposits.

The major objective of the study is to present documentation of sedimentary effects of two large Warta River floods (June 2010, January 2011) in the river valley near Poznań (Poland; Fig. 2A). This section of the Warta River consists of a natural floodplain (south of Poznań) and a portion in which the course of the river valley is regulated and limited by flood embankments (in Poznań; Fig. 2B). Many lowland rivers in Europe have been regulated for centuries. Thus the study of flood de- posits in both natural and engineered systems are important for the applications of sedimentology in river-flood hazard assessment (e.g., Klasz et al., 2014).

This study assesses particularly the two following issues:

- if summer and winter floods produce variable sedimentary records;

- if the sedimentary records of floods are significantly altered by early postdepositional changes during the twoyear post-flood period. 
Table 1

Average and extreme water levels and water discharges of Warta River in Poznań

\begin{tabular}{|l|c|c|}
\hline \multicolumn{2}{|c|}{$\begin{array}{c}\text { Water level } \\
{[\mathrm{cm}]}\end{array}$} & $\begin{array}{c}\text { Water discharge } \\
{\left[\mathrm{m}^{3} / \mathrm{s}\right]}\end{array}$ \\
\hline \multicolumn{3}{|c|}{$\begin{array}{c}\text { Characteristic states of the Warta River in Poznań } \\
\text { in period 1946-1990 }\end{array}$} \\
\hline Extreme - 26.03.1947 & 728 & 1035 \\
\hline Average high & 484 & 356 \\
\hline Average & 268 & 111 \\
\hline Average low & 164 & 41 \\
\hline Lowermost - 09.01.1985 & 93 & 22.5 \\
\hline \multicolumn{3}{|c|}{ Large floods } \\
\hline \multicolumn{3}{|c|}{ After the regulation of the river (in 1978 year) } \\
\hline 03.1979 & 700 & 832 \\
\hline After building the storage reservoir “Jeziorsko" (in 1988 year) \\
\hline 06.2010 & 667 & 630 \\
\hline 01.2011 & 599 & 479 \\
\hline
\end{tabular}

Water level data are for river gauge station (Roch Bridge; Fig. 2B), where $0 \mathrm{~cm}$ level is fixed at $49.46 \mathrm{~m}$ above sea level, $400 \mathrm{~cm}$ is assigned as a warning level and $450 \mathrm{~cm}$ is an alarm level. Presented data cover period from 1946 to 2012, the average values are based on period 1961-1990 (data after Institute of Meteorology and Water Management; Kaniecki, 2004)

\section{STUDY AREA}

The study was conducted in the area shaped by the Late Pleistocene ice sheets - primarily during the Weichselian glaciation. During the retreat of the last ice sheet, the major landforms affecting the modern river valley were formed. These landforms include the Warsaw-Berlin ice-marginal valley used by the modern Warta River in its latitudinal-oriented course and its northward-directed breakthrough part of the river valley. The latter was formed during the Chodzież subphase approximately 17,200 years BP (Kozarski, 1983, 1991). Studies by Bartkowski (1957), Witt (1974), Kozarski (1983), Antczak (1986), Gonera (1986), Kozarski et al. (1988) and Tobolski (1988) revealed that the Warta River changed from a braided river to a meandering river during the late Weichselian.

Currently, the Warta River is the third longest river in Poland (Fig. 2A). It is a lowland meandering river with average gradients of $0.46 \%$, and $\sim 0.18 \%$ near Poznań (Wiśniewski, 1995). In the study area, the valley cuts through areas of flat or undulating moraine and is primarily filled with Pleistocene and Holocene deposits. In some places, the river channel is cut in older clayey sediments of the Upper Miocene and Pliocene age (Bartkowski, 1957; Kozarski et al., 1988).

The study area is located in the middle section of the Warta River course (Fig. 2A) from the region of Krajkowo in the south to north of Poznań; it extends approximately $40 \mathrm{~km}$ along the course of the Warta (Fig. 2B). In the study section, the Warta valley varies from a natural broad valley (width of approximately $2 \mathrm{~km}$ ) in the south (areas of Krajkowo and Sowiniec) to a narrow valley zone (several hundreds of metres to several dozens of metres) in the breakthrough section (areas: Dębina, Lech Bridge, Naramowice railway bridge, and Naramowice Forest District).

From the nineteenth century until the 1970s, the Warta River in Poznań was subjected to artificial regulations that were aimed at flood protection. The banks of the Warta River within the city are currently reinforced with concrete slabs, and the valley is surrounded by flood embankments. The width and depth of the river in the vicinity of Poznań are dependent on the water level and range from 40 to $50 \mathrm{~m}$ and from 1.5 to $3.0 \mathrm{~m}$, respectively. The study areas of Krajkowo and Dębina are protected due to the existence of the water intake facilities for the city of Poznań.

\section{HYDROLOGICAL CHARACTERISTICS OF THE FLOODS IN 2010 AND 2011, AND THE FLOOD HISTORY IN THE POZNAŃ REGION}

High water levels in the Warta River occur seasonally - usually 1-2 times a year from winter to spring and/or during the summer. The snowmelt floods, which occur from March to April, are common and represent $80 \%$ of all floods during the last 450 years (Kaniecki, 2004). Summer floods, which are caused by long-lasting rains, are less frequent but are usually larger than the floods that occur during the winter and spring.

In May 2010, the highest water levels since 1979 were measured in the valley of the Warta River in the Poznan region (Table 1). In 1988, the reservoir "Jeziorsko" was constructed (approximately $200-\mathrm{km}$ upstream; Fig. 2A). Despite the considerable distance from Poznań, it has a significant impact on the water levels and discharge of the Warta River, particularly during floods (Miler, 2001). According to unpublished data from the Institute of Meteorology and Water Management, the 2010 flood in Poznań began on May 10, 2010 with an increase in water level from $270 \mathrm{~cm}$ (discharge of $115 \mathrm{~m}^{3} / \mathrm{s}$ ) to $667 \mathrm{~cm}$ (discharge of $630 \mathrm{~m}^{3} / \mathrm{s}$ ) on June 1, 2010. Thus, the flood persisted for three weeks (Figs. 1 and 3). The water alarm level $(450 \mathrm{~cm})$ was attained on June 16, 2010 (Fig. 3A).

A few months later, in November 2010, the next flood occurred, which persisted until February 2011 (Fig. 3B). The highest water level of $599 \mathrm{~cm}$ was measured January 22-23, 2011, when a river discharge of $479 \mathrm{~m}^{3} / \mathrm{s}$ was attained. During the winter flood, the water levels and water discharge were lower than the water levels and water discharge during the summer flood, whereas the winter flood lasted longer and was characterised by three distinct flood stages with rising and falling water levels (Fig. 3).

\section{METHODS}

The geological impacts of the 2010 and 2011 floods in the Warta River valley were assessed by surveys that were conducted during and immediately after the floods, when the river water level decreased to an average level. A total of six sites were investigated (Fig. 2B, C): A - Naramowice railway bridge, B - Lech Bridge, C - Krajkowo, D - Dębina, E - Sowiniec, and F - Naramowice forest district. Surveys were conducted in 2010 and 2011 in all six areas. In 2012, surveys were also conducted at Debina; samples from the bottom of the river channel were also collected during the low water level state of the Warta River (25.09.2012).

The survey at each site included photographic documentation during and after the flood, a record of erosional features, water flow direction indicators, damage to floodplain infrastructure and the distribution of flood sedimentary deposits. All features were mapped using GPS (76 sites). In each area, several shallow trenches were dug, documented and sampled (41 


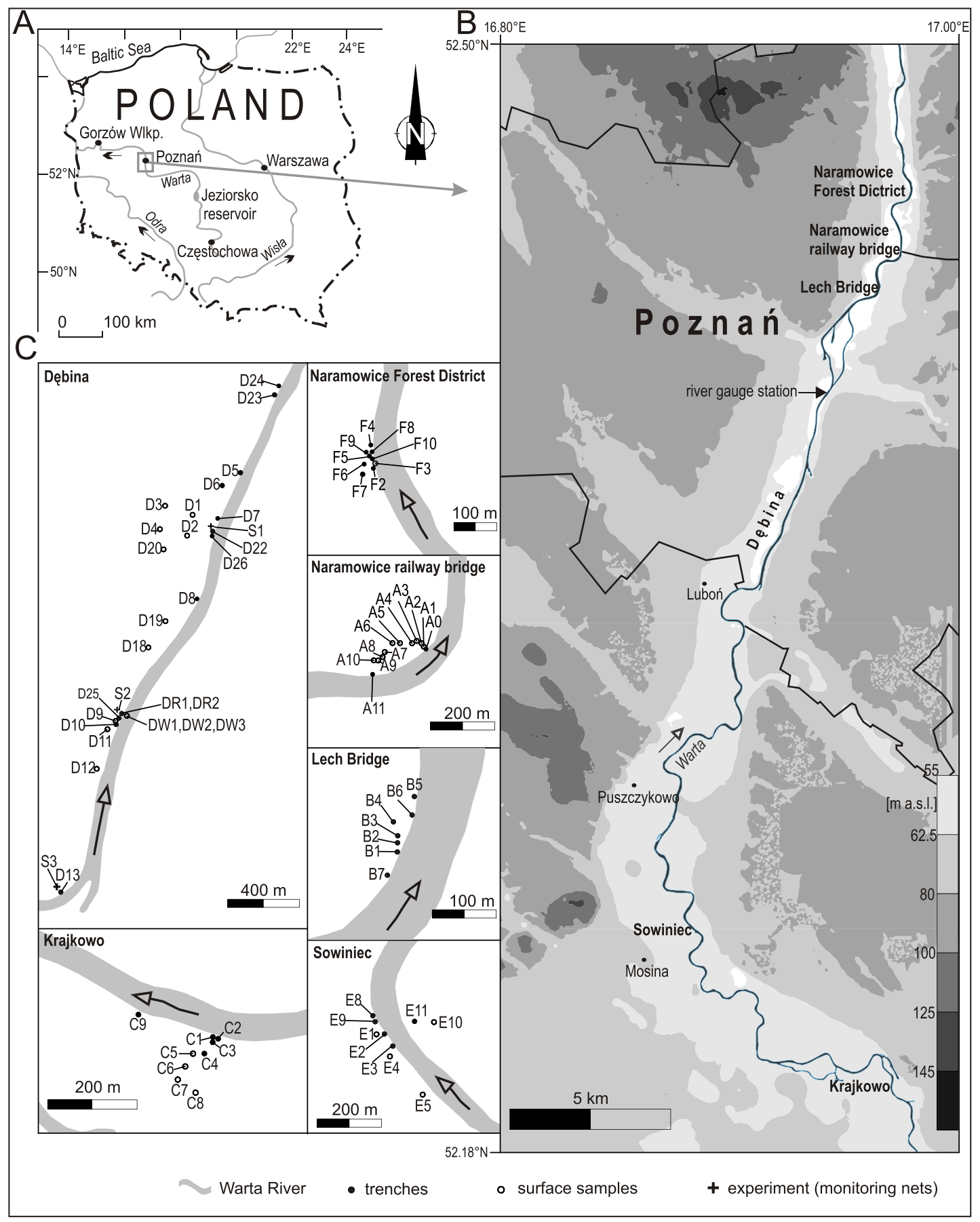

Fig. 2. Study area and sampling points

A - study area; B - Warta River valley near Poznań with 6 identified test areas (in bold); the location of the river gauge station and the borders of the city of Poznan (black line) are also marked; $\mathbf{C}$ - sketches of the study areas with marked positions of trenches, surface sampling sites and sites in which postdepositional changes were investigated (experiment sites)

trenches). Sediment samples for additional analysis were collected from flood deposits, underlying soils and river channels (208 samples - details on the sampling points are presented in Appendix $\left.1^{*}\right)$. Subsamples collected for geochemical analyses were presented by Kozak et al. (2012).
The grain-size distribution of all sediment samples were obtained through dry sieving at 0.5-phi intervals. Samples with high contents of fine-grained fractions were washed on a 4.0 phi sieve. The grain-size statistics were calculated with GRADISTAT software (Blott and Pye, 2001) by applying logarithmic

* Supplementary data associated with this article can be found, in the online version, at doi: 10.7306/gq.1179 
A

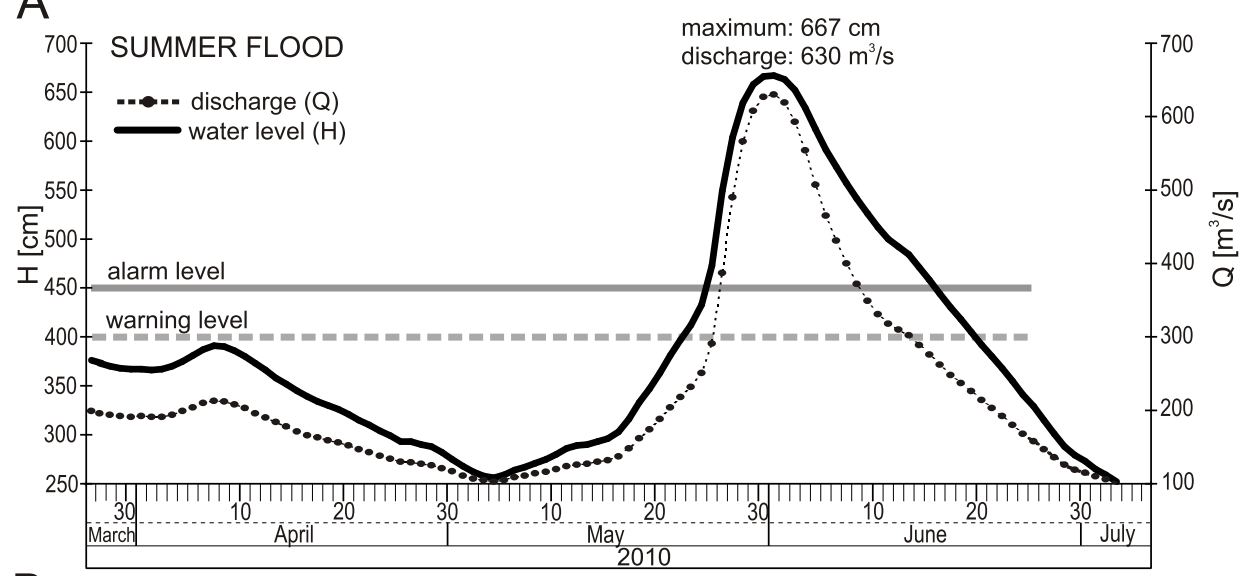

B

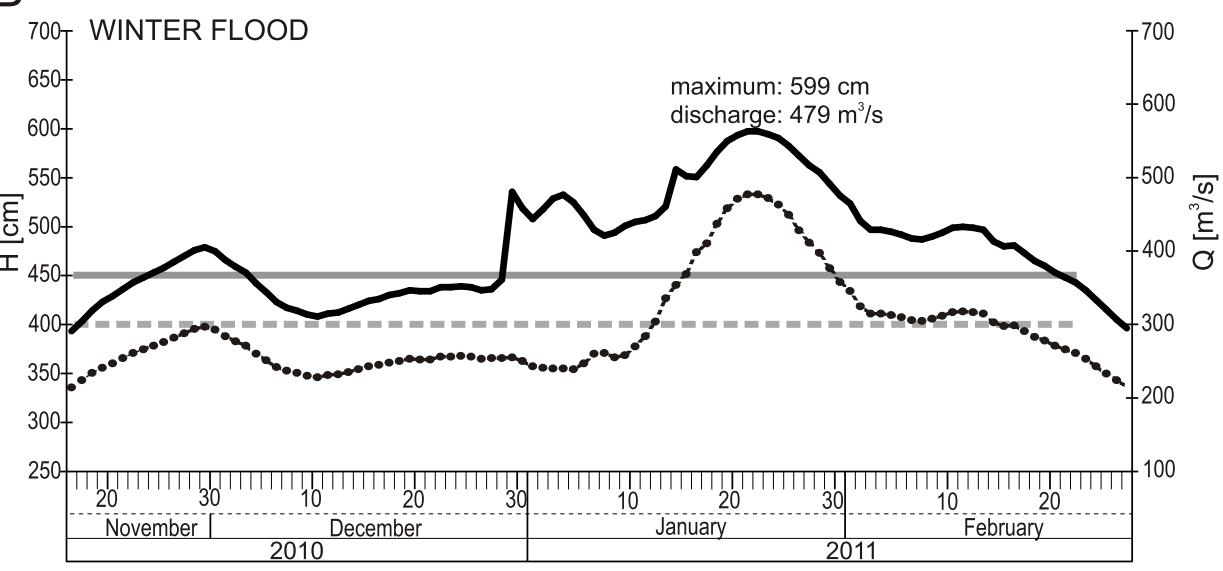

Fig. 3. Hydrographs of (A) the summer 2010 and (B) winter 2011 floods of the Warta River, as measured at the river gauge station (Fig. 2B)

Data were provided by the Institute of Meteorology and Water Management - National Research Institute

Folk and Ward graphical measures (1957). For 35 selected samples, grain-size fraction that ranged from 1.5-2.0 phi was analysed for major components. The identified quartz, feldspars, lithic grains, opaque minerals, plant remnants and shell fragments were counted under a binocular. Five samples in the fractions of 1.0-1.5 phi and 1.5-2.0 phi were analysed for the roundness of the quartz grain (angular, intermediate and rounded) and the character of the grain surface (shiny or matt) using the scale of Cailleux (1942) with modifications of Mycielska-Dowgiałło and Woronko (1998). Quartz grains in the fraction 1.0-1.5 phi were selected from two samples and analysed using a scanning electron microscope (SEM). The identification of surface microfeatures in the SEM images followed approach of Krinsley and Doornkamp (1973) and Mahaney (2002). In three samples of mud-algal mats, organic matter content was determined by the loss on ignition test at $550^{\circ} \mathrm{C}$.

The preservation of flood deposits was monitored by revisiting the majority of the sites that were documented immediately after the flood, one year after the flood and two years after the flood. In addition, three test sites were established in Dębina in August 2011 (Fig. 2C - points S1, S2, S3), where previously documented flood deposits were partly covered with a plastic net $(50 \times 50 \mathrm{~cm})$ for monitoring changes in surface sediments.
RESULTS

\section{EROSIONAL AND DEPOSITIONAL EFFECTS OF THE FLOODS}

The erosional and depositional forms were documented as the water level decreased, as many of the forms were ephemeral and could be subjected to natural reworking and anthropogenic restoration actions. The results are presented in Figures 4 and 5 . As the effects of the summer and winter floods were similar, they are described concurrently, with the exception of specific information.

\section{EROSION}

The erosional structures were identified only in specific places and were common for both floods. The most frequent features were undercuts of the river banks and the partial or total destruction of the vegetation cover on the river banks. The observation of microterraces formed during the gradual lowering of the water level during the late stages of the floods (Fig. $4 \mathrm{~A}$ ) was common along the banks. Crevasses were formed in 
several places, primarily during the winter flood. Common features included scours and associated shadow structures, which are related to trees (Fig. 4B) and other flow obstacles (e.g., wells on the Debina water intake). These features were common in the floodplain-proximal zone, which experienced rapid water flow.

Erosional features were rare on the grassy areas of the floodplains, especially in summer, when the grass cover was well-established. The most frequent sites for the creation of erosional niches were areas in which previous earth works had been performed, e.g., in relation to road projects and bridge construction (e.g., Lech Bridge, Fig. 4C). Their maximum depth exceeded $0.5 \mathrm{~m}$, and the area exceeded $10 \mathrm{~m}^{2}$. In the area of water intake, Dębina depressions several tens of centimetres deep were formed due to suffosion.

\section{DEPOSITION}

The most common flood sediments consisted of sands. Their spatial extent was restricted to a narrow (usually 2.5-3 m) zone close to the river channel. Sands were deposited primarily on well-developed levees and on side bars. In the case of crevasse splays, which formed when flood water destroyed the natural levees and deposited sediment on a floodplain, the extent of sandy deposits reached to a few dozen metres from the river channel bank. The thickness of the sandy deposits from the summer flood ranged from 10 to $15 \mathrm{~cm}$, with a maximum documented thickness of $40 \mathrm{~cm}$. Conversely, the winter flood deposits were thicker, with an average thickness of $30-35 \mathrm{~cm}$ and a maximum thickness of $70 \mathrm{~cm}$.
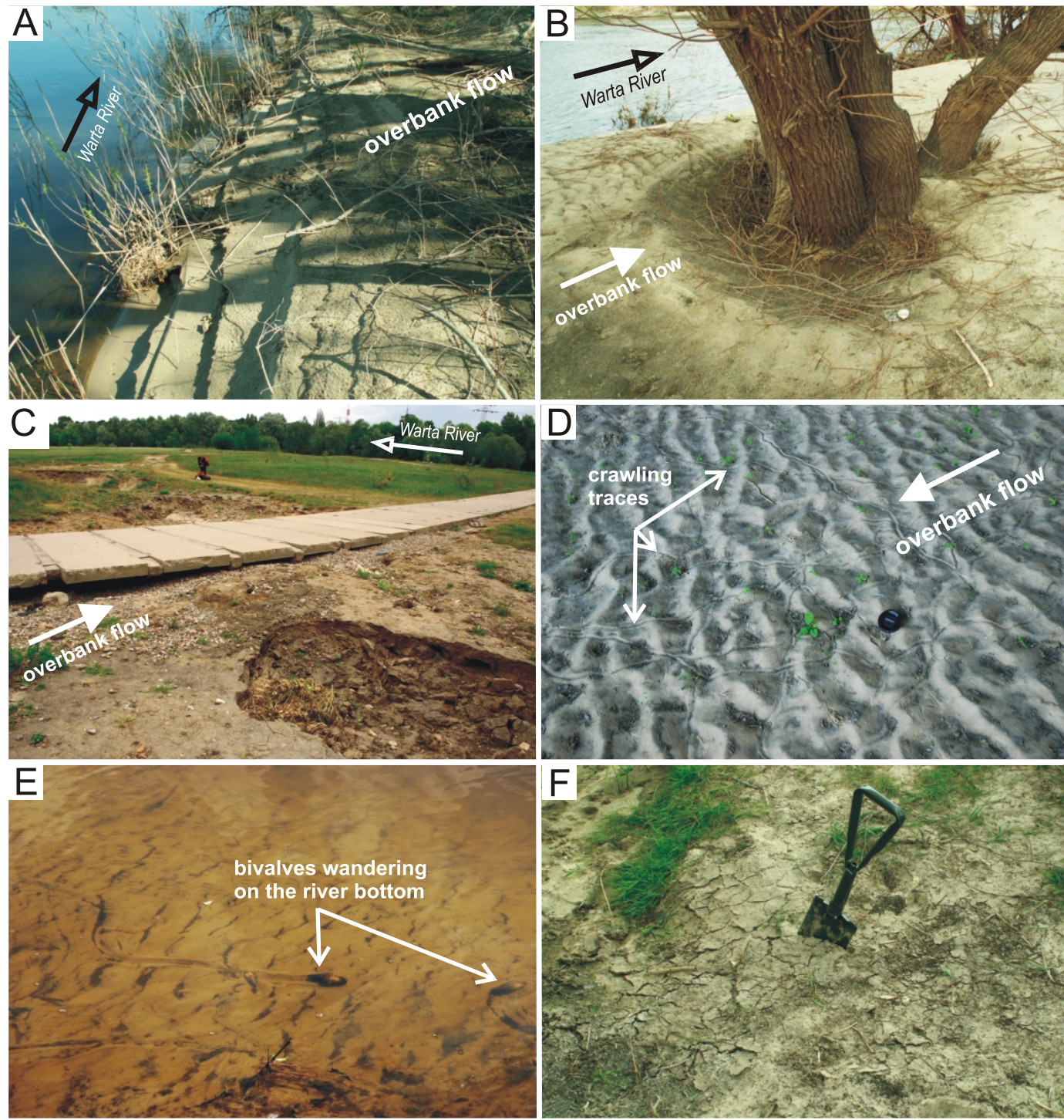

Fig. 4. Surface depositional and erosional features after the 2010 summer flood

A - microterraces on the sandy bank left after the water level receded (Dębina); B - deposition around trees, including scour, shadow structure and small current ripplemarks near the bank of the river (Dębina); C - erosional scours around the concrete road (Lech Bridge); D - small ripple marks with crawling traces produced by bivalves (Dębina); $\mathbf{E}$ - bivalves wandering in shallow water on the sandy bottom of the Warta River (average flow conditions) and leaving the same traces as in $\mathrm{D}$ (Dębina) and $\mathbf{F}$ - approximately 1-2 $\mathrm{mm}$ thick mud-algal mat after the summer flood (Sowiniec); refer to Figure 2B for place names 
Sedimentary structures were rarely detected in the sediments due to the homogeneous mineral composition and good sediment sorting. The most common structures included climbing-ripple lamination (thickness of single sets was on average 1-2 cm) and massive structures. On the sediment surface, the most common but ephemeral structures included small current ripples (Fig. 4B, D) and mollusc creep traces (Fig. 4D, E).

Thin layers of organic-rich muddy deposits, with a thickness of a few millimetres, were also frequently encountered. They were classified as muddy sands, as the average mud content ( $<4$ phi) was $23 \%$. They contained approximately $10 \%$ organic matter. These deposits were predominantly identified at a distance of several metres from the channel banks. After drying, their surfaces were marked with desiccation cracks (Fig. 4F).
Flood deposits were also observed in the form of organic deposits that were composed of shells and plant debris. Shell accumulations were detected in both the proximal and the distal part of the floodplain. They were composed of mussel and snail remnants, which were mixed and presented as well-preserved specimens (Fig. 5A) and crushed shells. They were located in specific areas, with a maximum coverage of a few square metres. A common form of accumulation consisted of plant debris (branches and grass), which were frequently aligned parallel to the direction of the current flow (Fig. 5B). The plant debris were frequently deposited during the rising flood water level, as they were often covered by sand and preserved in the flood deposits as layers or lenses (Fig. 5C, D). Extensive areas of the floodplains had not been covered by clastic deposits. The only depositional evidence
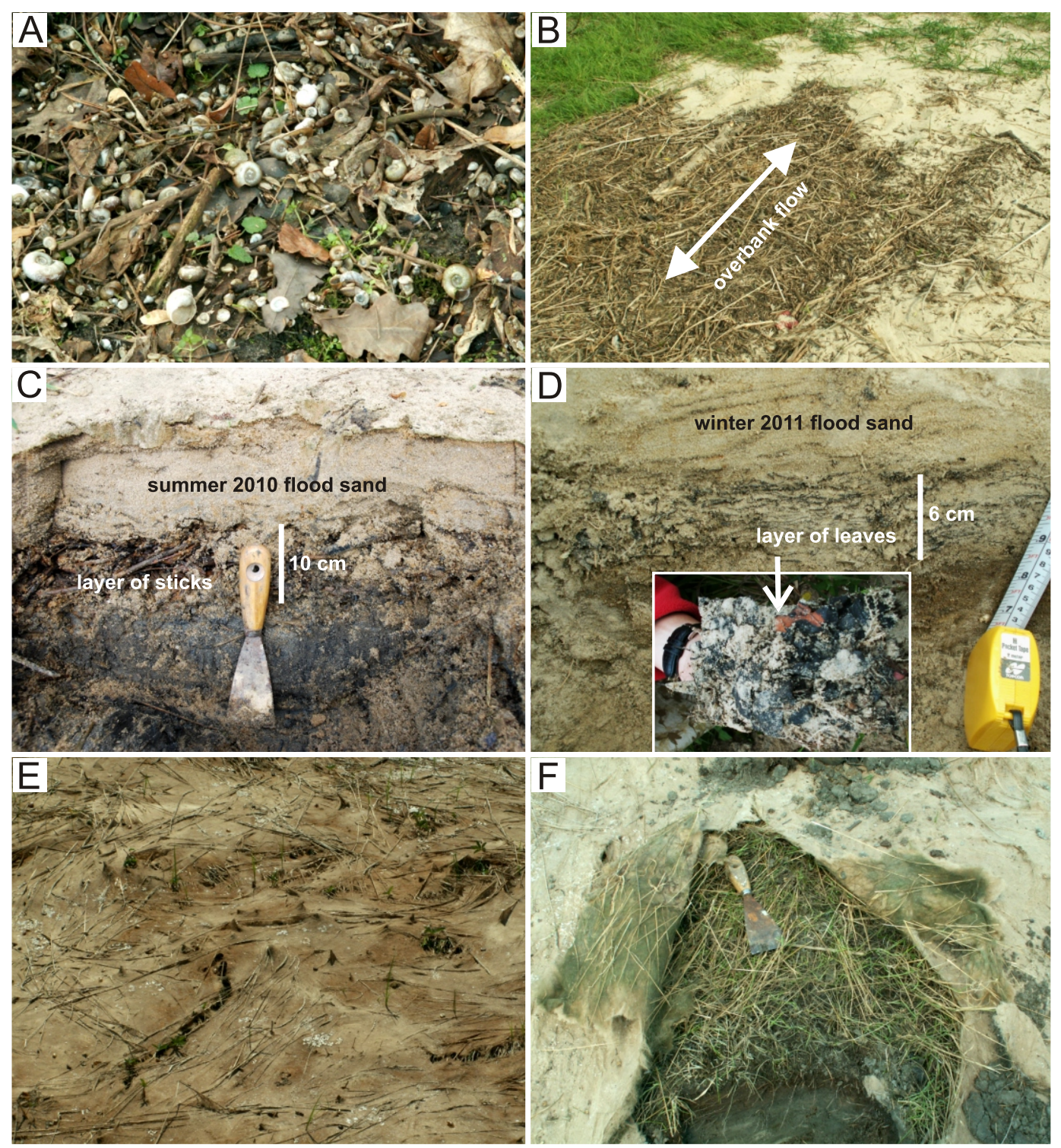

Fig. 5. The most common organic-rich flood deposits on the floodplain

A - shell lag deposits after the summer flood (Debina); B - accumulation of plant remains (mainly sticks), which are oriented parallel to the flow (Sowiniec); C - layer of sticks likely deposited by the rising flood water buried beneath summer flood sands (Debina); D - layer of leaves buried beneath winter flood sands (Sowiniec); E - continuous algal mat after the summer flood (Krajkowo); $\mathbf{F}$ - close-up of the mat from E, the mat covers pre-flood vegetation (Krajkowo) 
of flooding was a well-developed algal mat (e.g., Fig. 5E, F). The mats were only observed for the summer flood.

Grain-size distribution of flood deposits. Flood sands, analysed in 132 samples, appeared to be very similar in terms of grain-size distribution. They were classified as fine- and medium-grained sands with a mean grain size in the range of 1.51 to 2.84 phi (average 2.19 phi). The coarse fraction ( $<0.5$ phi) was primarily composed of shells and plant detritus. The sediments were well- to moderately well-sorted (standard deviation in the range of $0.27-0.61 \mathrm{phi}$ ). The skewness ranged from -0.07 to 0.39 , therefore the grain-size distributions were symmetrical, fine-skewed and very-fine-skewed. The kurtosis ranged from 0.86 to 1.5 ; thus, the most common type of distri- bution was platykurtic, but mesokurtic and leptokurtic distributions were also represented.

Muddy organic mats, which were analysed in 3 samples, were composed of fine and very fine sands that were poorly sorted (average standard deviation: 1.83 phi) with an average mean grain size of 3.27 phi. Fractions $<2$ phi were primarily composed of plant detritus.

When divided into sediments from levees, crevasse splays, other proximal floodplain forms, and distal floodplains, only the latter differed in terms of grain size (Fig. 6A). They were finer and poorly sorted. The comparison of deposits from the winter and summer floods revealed that the winter flood sands tended to be coarser and better sorted (Fig. 6B).
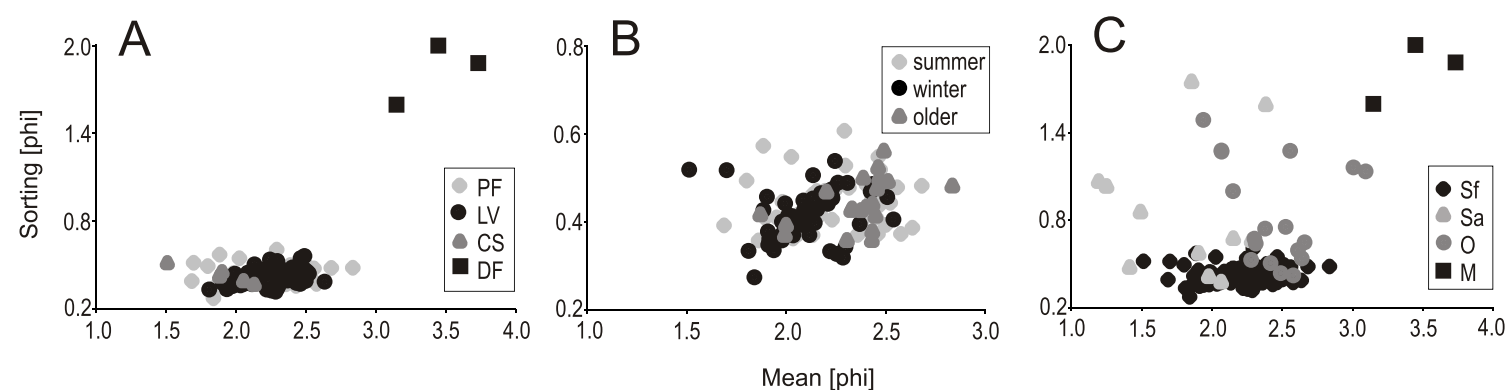

Fig. 6. Plots of mean grain size versus sorting for A - flood deposits from levees (LV), crevasse splays (CS), other proximal floodplain forms (PF), and distal floodplain (DF); B - flood sands classified as 2010 summer flood deposits (summer), the 2011 winter flood deposits (winter) and older sandy river deposits and C - all analysed samples classified into flood sands (Sf), mud-algal mats (M), pre-flood soils or organic-dominated sediments $(0)$ and anthropogenic sands redeposited during the flood (Sa)
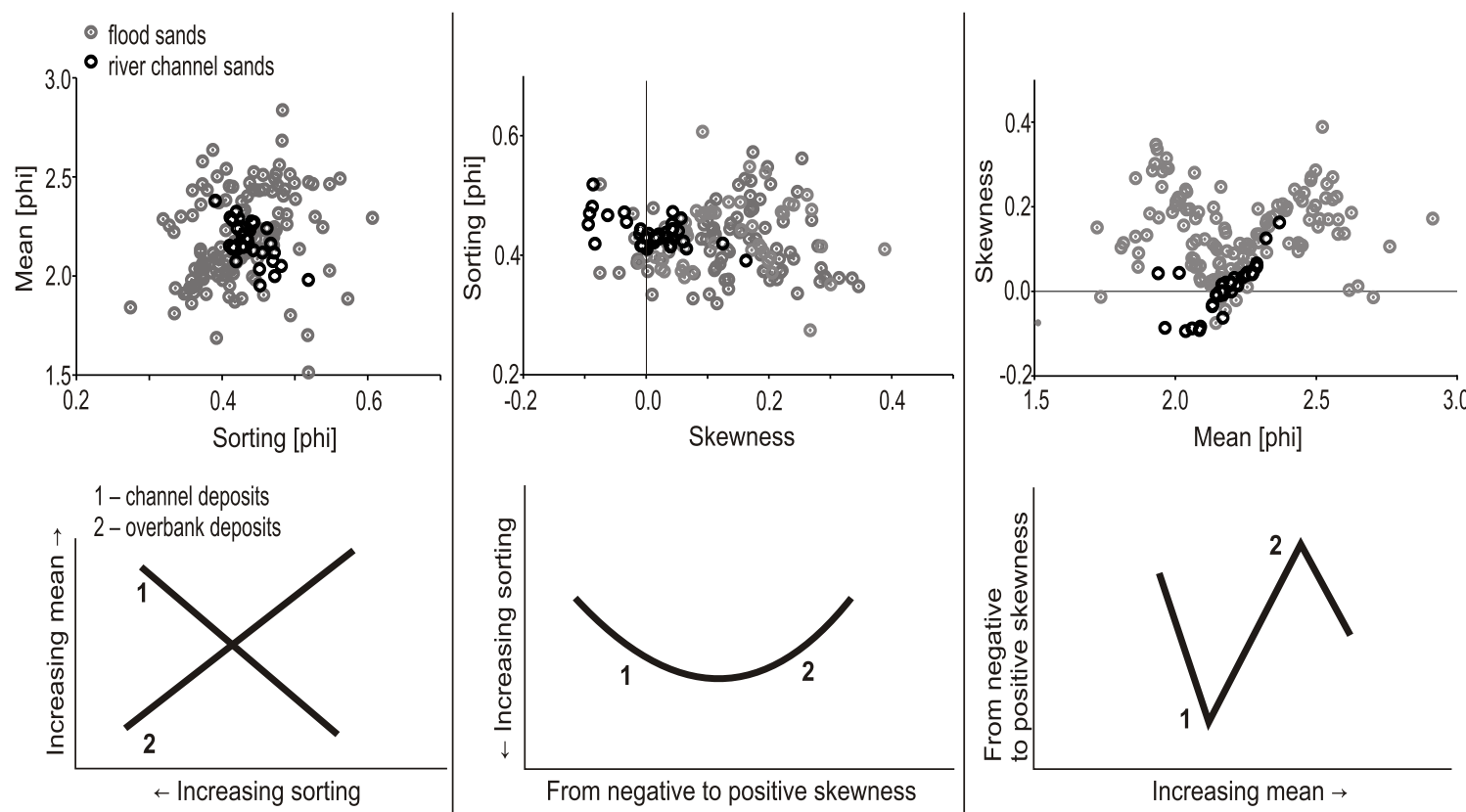

Fig. 7. Comparison of the sandy flood-deposits and modern Warta River channel deposits (collected during low-water discharge season near the flood impact sites)

Relation of grain-size statistics in sandy river sediments and trends in relations between grain-size parameters for fluvial sediments ( 1 - river channel sediments, 2 - overbank sediments) considered to be typical for fluvial deposits (after Mycielska-Dowgiałło and Ludwikowska-Kędzia, 2011) 
Grain-size distribution of non-flood deposits. The soils and organic matter-rich sediments and anthropogenic sands (delivered during earth works and redeposited during overbank flow) were analysed in 19 and 11 samples, respectively. They were distinctly different in terms of grain size statistics from the flood deposits (Fig. 6C). They covered an extensive range of grain sizes (from fine sand to medium sand) compared with flood deposits and were characterised by moderate to poor sorting.

The range of grain size statistics for the river channel deposits analysed in 43 samples fell within the range of flood sands (Fig. 7). However, the sandy deposits from floods tended to reveal the best sorting in the range of the finest fractions, whereas the samples from the river channel revealed that the coarser fractions were the best sorted. The flood deposits were mainly fine skewed, whereas the grain-size distributions of the river channel deposits tended to be symmetrical. The relationship between the mean grain size and the skewness of the flood deposits revealed a characteristic "zig-zag" pattern, whereas the river channel deposits tended to be characterized by more fine-skewed distributions in the sediments with a finer mean grain size (Fig. 7).

\section{COMPOSITION OF FLOOD SANDS}

The flood sands displayed a similar composition. They were dominated by quartz ( $88.5 \%$ on average), plant remnants $(3.5 \%)$, lithic grains $(3.5 \%)$, feldspars $(2.5 \%)$, opaque minerals $(1.5 \%)$ and shell fragments $(0.5 \%)$. Plant fragments and shell remnants were only present in some samples; the remaining components were present in all samples in similar amounts. The samples from the summer and winter floods do not show significant differences.

\section{ROUNDNESS AND MICROMORPHOLOGY OF QUARTZ GRAINS}

In terms of grain roundness and surface character, the most common grains in the flood sands were classified as follows: intermediate-shiny surface (55\%), intermediate-matt surface $(32 \%)$, angular $(10 \%)$, round-shiny surface $(1.5 \%)$ and roundmatt surface $(1.5 \%)$.

The grains from intermediate-shiny and round-shiny classes (Fig. 8A) were analysed with SEM (Fig. 8B). A common surface feature was chemical etching, as shown by the microstructure of the dulled surface (smooth polished surface) and the dissolution surface (rough), particularly in a microdepression (Fig. 8C). Only a few structures were produced by mechanical abrasion, such as single $v$-shaped percussion cracks (Fig. 8D), conchoidal fractures (Fig. 8E) and subparallel linear fractures. However, they were altered by the chemical weathering processes.

\section{POSTDEPOSITIONAL CHANGES}

The vast areas of floodplains were covered by algal mats during the summer flood, particularly at Krajkowo and Sowiniec (Fig. 5E, F), where they were often the only depositional effect
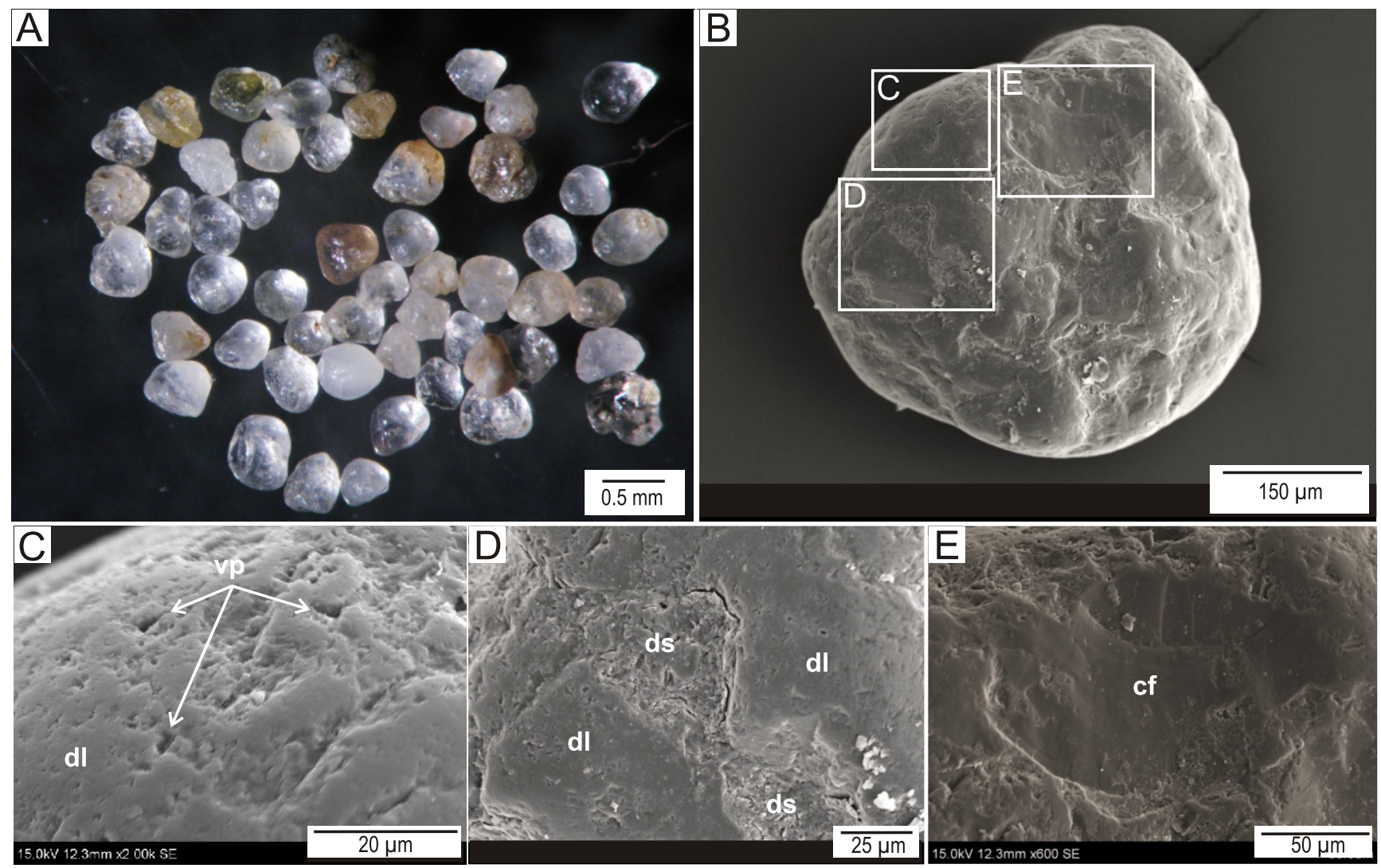

Fig. 8. Typical microfeatures of quartz grains in the $0.35-0.5 \mathrm{~mm}$ fraction

A - dominating polished and subrounded quartz grains; B - an example of rounded and polished quartz grain in SEM; C - example of grain surface with v-shaped percussion cracks (vp) and dulled surface (dl); $\mathbf{D}$ - example of grain surface with a dissolution surface (ds) and a dulled surface; E - example of grain surface with conchoidal fractures (cf) 


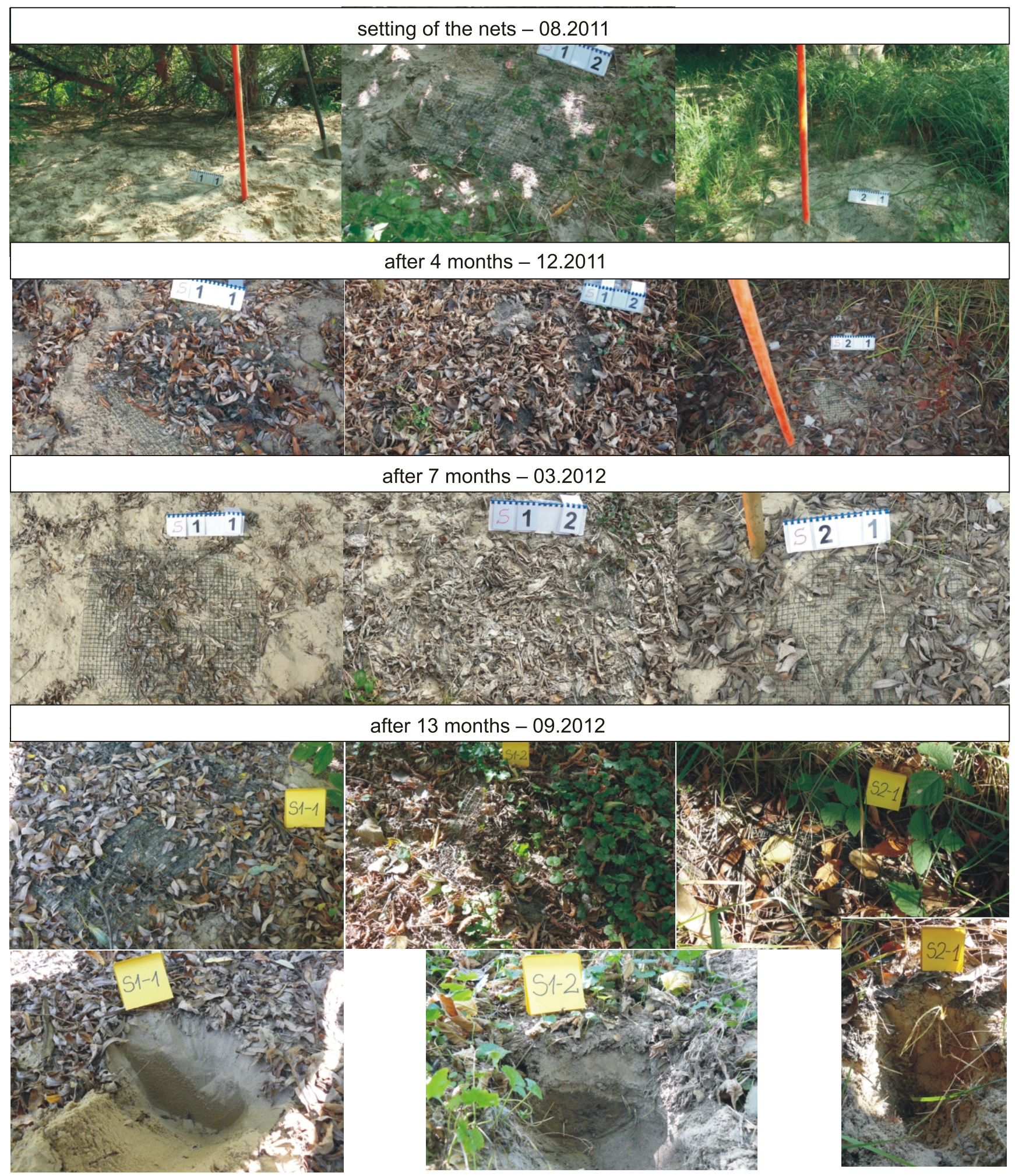

Fig. 9. Postdepositional history of the flood deposits in monitoring sites established in the Dębina water intake area (Fig. 2C)

The monitoring plots were partly covered by plastic nets to distinguish post-flood material; the surface sediments at sites S1-1, S1-2 and S2-1 are presented for the period immediately after the flood, 4 months after the flood, 7 months after the flood and 13 months after the flood; after 13 months, shallow pits were dug to verify the preservation of the flood deposits (last series of pictures) 
of the flood. After the floodplains dried, the mats remained for approximately one month; they were subsequently intersected by growing vegetation and decomposed.

The sandy flood deposits were well-preserved; however, the surface structures and upper parts of the deposits were rapidly reworked with little potential to be recorded in fossil flood deposits. The transformation of sediments was attributed to two periods: without cover vegetation (dominated by wind, rain, and human and animal activities) and after colonisation with plants (dominated by soil-forming processes). Among the observed effects associated with the first period, the most important effects were the redeposition of sand by wind, rain blurring, traces of living animals and humans (including traces of car wheels). Intensive wind transport observed during the field works contributed to the rapid transformation of fluvial forms of deposition into new forms - dunes with characteristic large-scale cross stratification and with a maximum height of several tens of centimetres. Rapid colonisation by vegetation (mainly grass) occurred in privileged places (days to weeks). However, in the case of thick sandy deposits, plant recovery was much slower (after two years, the sand was not covered by continuous vegetation). To document the rate of change, three experiments on control plots that were partly covered with mesh were conducted (Fig. 9). Nineteen months after the winter flood, the mesh was covered with living grass and plant debris (leaves and stems) in all places. In the case of a new flood, they may serve as a clear interflood layer.

The thickness is most likely the most important factor for the preservation of the deposits, as the several centimetre thick flood deposits were well-preserved after two years. At sites covered by thinner sand deposits or muddy sand deposits, the recognition of particular flood deposits after one vegetation season was hardly possible.

\section{DISCUSSION}

\section{THE SEDIMENTARY FLOOD RECORD} IN THE WARTA RIVER VALLEY

Floodplain deposition is primarily limited to the closest proximity of the river channel $(<2.5-3.0 \mathrm{~m})$ within the levees of the Warta River and is likely due to a nearly straight course that is artificially regulated. Although the extent of river flooding was relatively significant - in excess of $1 \mathrm{~km}$ - the water flow and sediment transport in the direction perpendicular to the river channel banks is considered to be small for rivers with a relatively straight course (James, 1985; Bathurst et al., 2002). Consequently, the dispersion of sediments is small and the sands predominantly produce levees. Their formation is likely related to turbulent eddies, which are responsible for sediment lifting and transferring from the channel to the near channel-bank zone. This mechanism of sand transport is defined as the turbulent diffusion of suspended material (Pizzuto, 1987; Marriott, 1992; Asselman and Middelkoop, 1995) and produces relatively thick sand accumulation close to the channel.

The investigated floods deposited little sediments from suspension (muds), although they are considered to be typical of floods. The limited suspension load in the transport and the hydraulic character of the flood waters in the straight course of the river are possible causes (Bathurst et al., 2002). The Warta River is a typical lowland river with a small slope and relatively flat catchment area. These factors may limit the delivery of fine-grained sediments from the catchment. The sediments from the upper course of the river are stored in the "Jeziorsko" reservoir. The straight course of the river through the southnorth oriented breakthrough part of the valley is potentially a transfer zone for suspension load, which is likely to be deposited in the parts of the valley with slower water flow.

The accumulations of large number of well-preserved snail shells (Fig. 5A) in some limited parts of floodplain may be related to migration of the snails during the summer flood from the channel margin toward the floodplain because of food availability (Tatsuaki Nakato, pers. comm., 2014). Rapid change of the conditions during recession of flood waters could cause that they could not follow and died out leaving a discontinuous layer of shells.

Floodplains are frequently characterized by significant local variability in sedimentation (Asselman and Middelkoop, 1995), which is confirmed by the results of this study. For example, the winter and summer floods produced deposits in various areas and amounts. The major depositional areas of the summer flood were not affected by the winter flood. As consecutive floods may produce deposits in different places, the sedimentary record of floods from a single site is likely to be incomplete. Similar observations were obtained by Lehotský et al. (2010). They found that depositional effects of the flooding of the Danube River in Bratislava from 2002-2007 were different in terms of the amount of accumulated sediment, sediment texture and spatial distribution.

FLOOD HYDRODYNAMICS - INSIGHTS FROM PROPERTIES OF FLOOD DEPOSITS

Sediment properties are commonly used to decipher hydrodynamic (e.g., palaeoflow) conditions during their deposition. To estimate the water flow regime during the accumulation of levees, we used a diagram by Sly et al. (1983) that discriminates the lower and upper flow regime depending on the skewness and the kurtosis. The deposits of the levees formed during the studied floods correspond to the conditions of the lower flow regime. These flow conditions are also confirmed by the observed sedimentary structures, e.g., small-scale ripple stratification (Singh, 1972).

Water flow velocity was also estimated using the median value of the samples from the levees, which is $0.22 \mathrm{~mm}$, and using the model of Miller et al. (1977). This model assumes one-directional flow conditions, provides the velocity at a depth of $100 \mathrm{~cm}$ above the bed and is dedicated to sediments that are primarily composed of quartz and feldspars. The calculated velocity is $0.4 \mathrm{~m} / \mathrm{s}$, which corresponds with the observed water velocities during the summer flood. The maximum velocities, which were measured next to the river gauge station (Fig. 2B), were $1.9 \mathrm{~m} / \mathrm{s}$ in the main river channel and $0.5 \mathrm{~m} / \mathrm{s}$ on the floodplain (data according to the Institute of Meteorology and Water Management - National Research Institute).

The sediment properties also provided insight into the deposition mechanism, e.g., from the bedload or graded suspension. For sandy flood deposits (especially levees), a distinct increase in the average grain size with sorting was observed. This trend is common in overbank river sediments (Mycielska-Dowgiałło, 1995; Kaczmarczyk et al., 2008; Mycielska-Dowgiałło and Ludwikowska-Kędzia, 2011; Szmańda, 2011). During the flood, sorting processes prevail within the coarser fractions, and the finer material that is deposited from suspension is less sorted and enriched in the fine-grained fraction, which results in fineskewed grain size distributions. 
Grain features provide information about sediment sources and transport mechanism. The similarity of the grain size distributions of flood deposits and the river channel sediments indicates a short overbank transport. The similarity also suggests the limited contribution of external sediment sources. The SEM studies show that the flood deposits consist of multiple times reworked river sediments. The smooth surface of the grains dulled surface - was caused by the dissolution of the surface and the simultaneous transport in an aqueous environment. These grain features are interpreted by Woronko and Ostrowska (2009) as common features of a fluvial environment in conditions in which the river reworks the older fluvial sediments. A confirmation of the interpretation that the flood deposits primarily originate from the river channel is the presence of bivalves and snails. Alexandrowicz (1998) demonstrated shell accumulations deposited during floods on the floodplain, reflecting the short transport from the bottom of the river instead of the adjacent areas.

\section{DIFFERENCES IN THE SEASONAL FLOOD RECORDS}

The summer and winter floods differ with regards to spatial distribution of the accumulation sites, the amount of sediments and their grain size. The winter flood deposited sands in a greater number of places, and the flood deposits were thicker. These deposits were coarser. Several potential reasons explain these differences; the winter flood was longer but the temperature and plant coverage may also be the factors. The temperature of the winter river-water is a few centigrade, close to the temperature for the maximum water density, thus water viscosity is relatively high. These conditions enable a larger amount of material to be transported by the river compared with conditions during the summer. During the summer, the water flow on the floodplains is restricted by growing plants, and the sediment/soils are well-stabilised by growing roots. On contrary, during the winter, as also observed during the case study, the ability to generate crevasses increases (Teisseyre, 1985). However, the composition of the flood deposits and the grain roundness and surface features do not differ between the summer and winter floods.

\section{THE PRESERVATION POTENTIAL OF FLOOD DEPOSITS}

In the temperate climate zone, where the floodplains are predominantly overgrown with vegetation, the postdepositional transformation of modern flood deposits occurs rapidly (they begin immediately after the flood water recedes). Our two-year observation revealed that thin muddy and sandy deposits were not likely to be preserved in a geological record. Thicker deposits may be preserved and are rapidly covered by a new organic-rich soil horizon, enabling their identification. Our observations are consistent with the conclusions of Teisseyre (1988). $\mathrm{He}$ conducted studies of the rivers in southern Poland for three years and determined that all mud deposits were reworked to various extents and were included in the soil profile.

\section{CONCLUSIONS}

This study documented the effects of two relatively large floods (summer 2010 and winter 2011) on a relatively straight, partly regulated, meandering river in a temperate climatic zone. The deposition during the floods only focused on the near river channel zone, which was dominated by layers of sands with a maximum thickness of $70 \mathrm{~cm}$. Almost no deposition was detected on the majority of the floodplain. The composition of the two floods revealed that they differed in the sedimentological record. During the winter flood (longer duration but with a slightly smaller magnitude than the summer flood) more sediment was deposited along the channel banks, and the deposited sediments were slightly coarser. As the depositional areas of both floods differed, potential palaeoflood reconstructions must consider the spatial depositional variability. The deposition occurred in a low energy regime with a reconstructed water flow velocity of $0.4 \mathrm{~m} / \mathrm{s}$, which was similar to the actual measured velocities. The flood deposits of a lowland river in a temperate climate, in which the floodplain is covered with vegetation, are rapidly subjected to colonisation by vegetation, which blurs the shape of forms and primary depositional features of sedimentary deposits. In this case, deposits must be at least several centimetres thick to be preserved. The postdepositional alternations of thinner deposits cause their effective removal within a single year.

Acknowledgements. This study was supported by the Ministry of Science and Higher Education, grant No. NN 304 105240. The authors are grateful to the Aquanet S.A. Company for access and permission to conduct research in the water intake area. The Institute of Meteorology and Water Management - National Research Institute kindly provided data on water levels, discharges and flow velocity of the Warta River for 2010 and 2011. We acknowledge D. Kasztelan who assisted with the documentation map and A. Rojewska for her collaboration during the SEM analyses. We thank J. Przybyłek and T. Zieliński for their discussion about the results. Comments from reviewers T. Kalicki and T. Nakato helped us to improve the manuscript and we gratefully acknowledge their efforts. We would also like to thank T.M. Peryt and W. Granoszewski for editorial support.

\section{REFERENCES}

Alexandrowicz, S.W., 1998. Thanatocoenoses of molluscs from flood deposits in Imbramowice near Cracow (in Polish with English summary). Dokumentacja Geograficzna, 11: 69-83.

Antczak, B., 1986. Channel pattern conversion and cessation of the Warta River bifurcation in the Warsaw-Berlin pradolina and the southern Poznań gap section during the Late Vistulian (in Polish with English summary). Zeszyty Naukowe UAM Poznań, seria Geografia, 35 
Asselman, N.E.M., Middelkoop, H., 1995. Floodplain sedimentation: quantities, patterns and processes. Earth Surface Processes and Landforms, 20: 481-499.

Bartkowski, T., 1957. Die Entwicklung des postglazialen Entwässergungssystem im mittleren Grosspolen (in Polish with German summary). Zeszyty Naukowe UAM Poznań, seria Geografia, 1: 3-79

Bathurst, J.C., Benson, I.A., Valentine, E.M., Nalluri, C., 2002 Overbank sediment deposition patterns for straight and meandering flume channels. Earth Surface Processes and Landforms, 27: 659-665.

Benito, G., Sánchez-Moya, Y., Sopeña, A., 2003. Sedimentology of high-stage flood deposits of the Targus River, Central Spain. Sedimentary Geology, 157: 107-132.

Bissolli, P., Friedrich, K., Rapp, J., Ziese, M., 2011. Flooding in eastern central Europe in May 2010 - reasons, evolution and climatological assessment. Weather, 66: 147-153.

Blott, S.J., Pye, K., 2001. Gradistat: a grain size distribution and statistics package for the analysis of unconsolidated sediments. Earth Surface Processes and Landforms, 26: 1237-1248.

Brierley, G.J., Ferguson, R.J., Woolfe, K.J., 1997. What is a fluvial levee? Sedimentary Geology, 114: 1-9.

Cailleux, A., 1942. Les actions éoliennes périglaciaires en Europe. Société géologique de France, Memoire, 41.

Falkowski, E., 1975. Variability of channel processes of lowland rivers in Poland and changes of the valley floors during the Holocene. Biuletyn Geologiczny, 19: 45-78.

Farrell, K.M., 1987. Sedimentology and facies architecture of overbank deposits of the Mississippi River, False River region, Louisiana. Journal of Sedimentary Petrology, 57: 111-120.

Ferguson, R.J., Brierley, G.J., 1999. Levee morphology and sedimentology along the lower Tuross River, south-eastern Australia. Sedimentology, 46: 627-648.

Folk, R.L., Ward, W.C., 1957. Brazos River bar: a study in the significance of grain size parameters. Journal of Sedimentary Petrology, 27: 3-26.

Fraselle, Q., Bousmar, D., Zech, Y., 2010. Experimental investigation of sediment deposition on floodplains. In: Proceedings of the River Flow 2010 Conference, Vol. 1 (eds. A. Dittrich, J. Koll, J. Aberle and P. Geisenhainer): 823-830.

Gębica, P., Sokołowski, T., 2001. Sedimentological interpretation of crevasse splays formed during the extreme 1997 flood in the upper Vistula river valley (South Poland). Annales Societatis Geologorum Poloniae, 71: 53-62.

Gomez, B., Phillips, J.D., Magilligan, F.J., James, L.A., 1997. Floodplain sedimentation and sensitivity: summer 1993 flood, upper Mississippi River valley. Earth Surface Processes and Landforms, 22: 923-936.

Gonera, P., 1986. Changes in geometry of the Warta meandering channels against climatic fluctuations during the Late Vistulian and Holocene (in Polish with English summary). Wyd. Naukowe UAM Poznań, seria Geografia, 33.

Hudson, P.F., 2005. Natural Levees. In: Encyclopedia of Water Sciences. Taylor \& Francis.

Iseya, F., 1989. Mechanism of inverse grading of suspended load deposits. In: Sedimentary Facies in the Active Plate Margin (eds. A. Taira and F. Masuda): 113-129.

James, C.S., 1985. Sediment transport to overbank section. Journal of Hydraulic Research, 23: 435-452.

Kaczmarczyk, M., 2010. http://www.city.poznan.pl/mapa geopoz/ data/wizualizacja/index.php?sciezka=../wizualizacja/powodz 2010/, July 2014

Kaczmarczyk, J., Florek, W., Olszak, I.J., 2008. Late Holocene and recent landforms and floodplain deposits in the middle Wieprza valley (in Polish with English summary). Landform Analysis, 7: 80-94.

Kalicki, T., 1996. Overbank deposits as indicator of the changes in discharges and supply of sediments in the upper Vistula valley the role of climate and human impact. Geographical Studies, $\mathbf{9}$ : 43-60.
Kalicki, T., 2000. Grain size of the overbank deposits as carries of paleogeographical information. Quaternary International, 72 107-114

Kaniecki, A., 2004. Poznan - the History of the City Written with Water (in Polish with English summary). Publishing House of the Poznań Society for the Advancement of the Arts and Sciences.

Khan, N.S., Horton, B.P., McKee, K.L., Jerolmack, D., Falcini, F., Enache, M.D., Vane, C.H., 2013. Tracking sedimentation from the historic A.D. 2011 Mississippi River flood in the deltaic wetlands of Louisiana, USA. Geology, 41: 391-394.

Klasz, G., Reckendorfer, W., Gabriel, H., Baumgartner, C., Schmalfuss, R., Gutknecht, D., 2014. Natural levee formation along a large and regulated river: the Danube in the National Park Donau-Auden, Austria. Geomorphology, 215: 20-33.

Krinsley, D., Doornkamp, J.C., 1973. Atlas of Sand Grain Surface Textures. Cambridge University Press, Cambridge.

Kozak, L., Skolasińska, K., Niedzielski, P., 2012. Environmental impact of flood: the study of arsenic speciation in exchangeable fraction of flood deposits of Warta river (Poland) in determination of "finger prints" of the pollutants origin and the ways of the migration. Chemosphere, 89: 257-261.

Kozarski, S., 1983. River channel changes in the middle reach of the Warta Valley, Great Poland, Lowland. Quaternary Studies in Poland, 4: 159-169.

Kozarski, S., 1991. Warta - a case study of lowland river. In: Template Paleohydrology (eds. L. Starkel, K.J. Gregory and J.B. Thornes): 189-215. John Wiley and Sons, Chichester, UK.

Kozarski, S., Gonera, P., Antczak, B., 1988. Valley floor development and paleohydrological changes: the Late Vistulian and Holocene history of the Warta river (Poland). In: Lake, Mire and River Environments During the Last 15000 Years (eds. G. Lang and C. Schluchter): 185-203. Balkema, Rotterdam.

Kundzewicz, Z.W., Lugeri, N., Dankers, R., Hirabayashi, Y., Doell, P., Pinskwar, I., Dysarz, T., Hochrainer, S., Matczak, P. 2010. Assessing river flood risk and adaptation in Europe - review of projections for the future. Mitigation and Adaptation Strategies for Global Change, 15: 641-656.

Lehotský, M., Novotný, J., Szmańda, J.B., 2010. Response of the Danube River floodplain to flood events during 2002-2007 period. Quaestiones Geographicae, 29: 37-45.

Mahaney, W.C., 2002. Atlas of Sand Grain Surface Textures and Applications. Oxford University Press.

Marriott, S., 1992. Textural analysis and modeling of a flood deposit: River Severn, U.K. Earth Surface Processes and Landforms, 17: 687-697.

Miler, A.T., 2001. Influence of the Jeziorsko reservoir on the Warta River discharges at the Poznań (in Polish with English summary). Kompleksowe i szczegółowe problemy inżynierii środowiska, Scientific Conference in Ustronie Morskie: 735-743.

Miller, M.C., McCave, I.N., Komar, P.D., 1977. Threshold of sediment motion under unidirectional currents. Sedimentology, 24: 507-527.

Milly, P.C.D., Wetherald, R.T., Dunne, K.A., Delworth, T.L., 2002 Increasing risk of great floods in a changing climate. Nature, 415: 514-517.

Mycielska-Dowgiałło, E., 1995. Selected textural features of deposits and their interpretation value (in Polish with English summary). In: Badania osadów czwartorzędowych. Wybrane metody i interpretacja wyników (eds. E. Mycielska-Dowgiałło and J. Rutkowski), Warszawa: 29-105.

Mycielska-Dowgiałło, E., Ludwikowska-Kędzia, M., 2011. Alternative interpretations of grain-size data from Quaternary deposits. Geologos, 17: 189-203.

Mycielska-Dowgiałło, E., Woronko, B., 1998. Rounding and frosting analysis of quartz grains of sand fraction, and its interpretive value (in Polish with English summary). Przegląd Geologiczny 46: $1275-1281$.

Pizzuto, J., 1987. Sediment diffusion during overbank flows. Sedimentology, 34: 301-317. 
Singh, I.B., 1972. On the bedding in the natural-levee and the point bar deposits of the Gomti River, Uttar Pradesh, India. Sedimentary Geology, 7: 309-317.

Skolasińska, K., Rotnicka, J., 2011. Pozakorytowe osady Warty zdeponowane w czasie powodzi zimowej 2010/2011 na zakolu rzeki w Marlewie (Poznań S) (in Polish). In: Varia. Prace z zakresu geografii i geologii (eds. J. Biernacka and J. Kijowska): 7-25. Bogucki Wydawnictwo Naukowe, Poznań.

Sly, P.G., Thomas, R.L., Pelletier, B.R., 1983. Interpretation of moment measures derived from water-lain sediments. Sedimentology, 30: 219-233.

Smith, G.H.S., Best, J.L., Ashworth, P.J., Lane, S.N., Parker, N.O., Lunt, I.A., Thomas, R.E., Simpson, C.J., 2010. Can we distinguish flood frequency and magnitude in the sedimentological record of rivers? Geology, 38: 579-582.

Smith, N.D., Pérez-Arlucea, M., 2008. Natural levee deposition during the 2005 flood of the Saskatchewan River. Geomorphology, 101: 583-594.

Szmańda, J., 2011. Record of depositional conditions in grain size composition of overbank deposits (in Polish with English summary). Landform Analysis, 18.

Szmańda, J., Oczkowski, H., Przegiętka, K., 2004. Age of the Vistula river overbank deposits in Toruń. Geochronometria, 23 35-38.

Teisseyre, A.K., 1985. Recent overbank deposits of the Sudetic valleys, SW Poland. Part I: General environmental characteristics (with examples from the upper river Bóbr drainage basin (in Polish with English summary). Geologica Sudetica, 20: 113-195.

Teisseyre, A.K., 1988. Recent overbank deposits of the Sudetic valleys, SW Poland. Part III: Subaerially and subaqueously deposited overbank sediments in the light of field experiment (1977-1979) (in Polish with English summary). Geologia Sudetica, 23: 1-55.

Tobolski, K., 1988. Paleobotanical study of Bölling sediments of Żabinko in the vicinity of Poznań, Poland. Quaestiones Geographicae, 10: 119-124
Wierzbicki, G., Ostrowski, P., Mazgajski, M., Bujakowski, F., 2013. Using VHR multispectral remote sensing and LIDAR data to determine the geomorphological effects of overbank flow on a floodplain (the Vistula River, Poland). Geomorphology, 183: 73-81.

Wiśniewski, J., 1995. Przebudowa poznańskiego węzła wodnego zabezpieczeniem przed powodzią Poznania (in Polish). In: Wody powierzchniowe Poznania, problemy wodne obszarów miejskich (eds. A. Kaniecki and J. Rotnicka): 224-233. Scientific Conference in Poznań.

Witt, A., 1974. Reconstruction of direction of Warta outflow in the highest terrace level of gap of the Warta valley near Poznań (in Polish with English summary). Badania Fizjograficzne nad Polską Zachodnia, seria Geografia Fizyczna, 27: 179-208.

Woronko, B., Ostrowska, M., 2009. The influence of fluvial environment on the character of quartz grain surface - a discussion (in Polish with English summary). Geneza, litologia i stratygrafia utworów czwartorzędowych, 5, seria Geografia, 88: 607-625.

Zajaczkowski, M., Darecki, M., Szczuciński, W., 2010. Report on the development of the Vistula River plume in the coastal waters of the Gulf of Gdańsk during the May 2010 flood. Oceanologia, 52: 311-317.

Zieliński, T., 2001. Erosional effects of catastrophic flood in the Nysa Klodzka drainage basin during the 1997 and 1998 events, SW Poland (in Polish with English summary). Przegląd Geologiczny, 49: 1096-1100.

Zieliński, T., 2003. Catastrophic flood effects in alpine/foothill fluvial system (a case study from the Sudetes Mts, SW Poland). Geomorphology, 54: 293-306.

Zwoliński, Z., 1985. Sedimentation vertical accretion of sediments on the Parsęta river floodplain (in Polish with English summary). Badania Fizjograficzne nad Polską Zachodnia, 35 (A): 205-238.

Zwoliński, Z., 1992. Sedimentology and geomorphology of overbank flows on meandering river floodplains. Geomorphology, 4: 367-379. 